\title{
EGFR NP_005219.2:p.D770_N771insGD
}

National Cancer Institute

\section{Source}

National Cancer Institute. EGFR NP 005219.2:p.D770 N771insGD. NCI Thesaurus. Code C98648.

An insertion of the amino acid sequence glycine-aspartic acid between the aspartic acid at position 770 and the asparag ine at position 771 of the epidermal growth factor receptor protein. 